ISSN 2616-7328 (Online), ISSN 2409-904X (Print)

Kitaêznavčì doslìdžennâ, 2019, No. 1, pp. 38-46 doi: https://doi.org/10.15407/chinesest2019.01.038

UDC 94(510)

\title{
HISTORICAL ALLUSIONS FOUND IN THE TEXTS OF MR. XI JINPING'S SPEECHES
}

\author{
V. Urusov \\ $\mathrm{PhD}$ (History)
}

This article deals with examples of historical allusions found in the texts of Mr. Xi Jinping's speeches. An explanation of the sources from Chinese classics is given. The importance of the historical heritage of Confucianism and the traditions of the State Administration of Antiquity for the development of Chinese society, from the point of view of modern Chinese researchers is highlighted.

Keywords: historical allusions, basic values of socialism, Socialism with Chinese characteristics, traditional culture, Confucianism

\section{ІСТОРИЧНІ АЛЮЗІЇ У ТЕКСТАХ ПРОМОВ СІ ЦЗІНЬПІНА}

\section{В. Б. Урусов}

Для розуміння процесів, що відбуваються в сучасному Китаї, необхідно бачити постійний зв’язок з історичним минулим різних епох у свідомості китайського суспільства. Це особливо важливо для усвідомлення того, що вкладають у Китаї у визначення соціалізму з китайською специфікою. Багатий матеріал для цього надають тексти виступів Голови КНР Сі Цзіньпіна, в яких активно використовуються історичні алюзії.

Для цієї статті обрано тексти 2014 та 2018 років, що пов'язані з традиційними моральними цінностями, традиціями управління державою, ставленням до навколишнього середовища.

У промові на зустрічі з викладачами та студентами Пекінського університету "Молодь повинна свідомо втілювати в життя основні цінності соціалізму” 4 травня 2014 року Сі Цзіньпін сказав:

«Китайська цивілізація налічує тисячі років і має унікальну систему цінностей. Видатна традиційна культура Китаю вже сформувала ген китайської нації, вкорінилася в душах китайців, непомітно впливає на їх способи мислення і поведінки. Сьогодні, коли ми відстоюємо і поширюємо основні цінності соціалізму, то повинні користатися цим багатством культури, бо інакше вони не матимуть життєвої сили і впливу. Наприклад, китайська культура підкреслює, що “народ - основа держави” (1), “небо і людина єдині” (2), “досягнення згоди за наявності розходжень" (3) підкреслює, що “небесні світила постійно рухаються, а благородний муж невтомний у самовдосконаленні” (4), “коли діють великі принципи, Піднебесна належить усім людям" (5), підкреслює, що “за зліт і падіння країни кожен несе відповідальність” (6). Китайська

2019 V. Urusov; Published by the A. Yu. Krymskyi Institute of Oriental Studies, NAS of Ukraine and the Ukrainian Association of Sinologists on behalf of The Chinese Studies. This is an Open Access article distributed under the terms of the Creative Commons Attribution License (https://creativecommons.org/licenses/by-nc-nd/4.0/). 
культура відстоює моральне управління і виховання людей переконанням, підкреслює, що “благородний муж розуміє належне” (7), “благородний муж щирий і чистосердечний” (8), що “благородний муж у справах справедливий” (9), підкреслює, що “слова потребують довіри, дії вимагають результату” (10), що “людина без довіри нічого не варта" (11); підкреслює, що “моральна людина не самотня, завжди будуть однодумці” (12), що “гуманний любить людей” (13), що необхідно “допомагати людям у добрих справах" (14), а "чого не бажаєте собі, не робити іншим” (15), “бути друзями, допомагати один одному в охороні і спостереженні за ворогом" (16), “шанувати старих, а також старих інших людей, турбуватися про дітей, а також про дітей інших людей” (17), “допомагати у скрутний момент”, “не боятися малої долі, а боятися нерівності” (18) тощо» [习近平谈治国理政 / 习近平著一北京：外文出版社，2014].

У цьому тексті містяться висловлювання з конфуціанської класики:

(1) 民惟邦本 (народ - основа держави) - “Шаншу” (“Велика книга”), глава “Уцзи чжи ге" (“Пісня п’ятьох братів").

(2) 天人合一 (небо і людина єдині) - точка зору давньокитайської філософіï. Походить із теорії волі неба періоду династії Чжоу, згідно з якою небо і людина міцно пов'язані між собою.

(3) 和而不同 (досягнення згоди за наявності розходжень) - “Луньюй” (“Бесіди і судження”), глава “Цзилу”.

(4) 天行健, 君子以自强不息 (небесні світила постійно рухаються, а благородний муж невтомний у самовдосконаленні) - “Чжоу ї” (“Книга змін”), глава "Цянь”. "Чжоу ї" - один із класичних канонів китайського конфуціанства. За допомогою восьми триграм (символізують 8 явищ природи: небо, земля, грім, вітер, вода, вогонь, гори, водойми) у “Чжоу ї" викладаються погляди, які сповнені примітивної діалектики, про зв'язок суспільних змін та змін у природі, про взаємодію сил “їнь" та “ян”, як першопричину всіх явищ у світі, про взаємний рух твердого та м'якого, що породжує усі зміни, тощо.

(5) 大道之行也, 天下为公 (коли діють великі принципи, Піднебесна належить усім людям) - “Ліцзі” (“Книга ритуалів”), глава “Ліюнь”.

(6) 天下兴亡, 匹夫有责 (за зліт і падіння країни кожен несе відповідальність) - Гу Яньу “Жичжилу” (“Записи щоденного пізнання”), глава “Чженши”. Оригінальний текст такий: "Кожен несе відповідальність за захист Піднебесної”. Гу Яньу (1613-1682) народився у місті Куньшань провінції Цзянсу, мислитель та історик кінця династії Мін, початку династії Цін.

(7) 君子喻于义 (благородний муж розуміє належне) - “Луньюй”, глава “Ліжень".

(8) 君子坦荡荡 (благородний муж щирий і чистосердечний) - “Луньюй”, глава "Шуер".

(9) 君子义以为质 (благородний муж у справах справедливий) - “Луньюй”, глава "Вей Лінгун”.

(10) 言必信, 行必果 (слова потребують довіри, дії вимагають результату) - “Луньюй”, глава “Цзилу”.

(11) 人而无信, 不知其可也 (людина без довіри нічого не варта) - “Луньюй”, глава “Вейчжен”.

(12) 德不孤, 必有邻 (моральна людина не самотня, завжди будуть однодумці) - “Луньюй”, глава “Ліжень”.

(13) 仁者爱人 (гуманний любить людей) - “Менцзи”, глава “Лілоу” 2-а частина. "Менцзи” - один із класичних канонів конфуціанства. Це збірка вислов- 
лювань Менцзи періоду Чжаньго, що була укладена Менцзи разом із його учнями. Разом із “Дасюе”, “Чжунюн”, “Луньюй” називається “Чотири книги”.

(14) 与人为善 (допомагати людям у добрих справах) - "Менцзи”, глава “Гусунь Чоу”, 1-а частина.

(15) 己所不欲, 勿施于人 (чого не бажаєте собі, не робити іншим) - “Луньюй”, глава “Яньюань”.

(16) 出入相友, 守望相助 (бути друзями, допомагати один одному в охороні і спостереженні за ворогом) - “Луньюй”, глава “Тен Веньгун”, 1-а частина.

(17) 老吾老以及人之老, 幼吾幼以及人之幼 (шанувати старих, а також старих інших людей, турбуватися про дітей, а також про дітей інших людей) “Менцзи”, глава “Лян Хуейван”, 1-а частина.

(18) 扶贫济困、不患寡而患不均 (допомагати у скрутний момент, не боятися малої долі, а боятися нерівності) - “Луньюй”, глава “Цзіши”.

Далі Сі Цзіньпін каже:

«По-третє, ми повинні чітко розрізнювати, вміти чітко розрізнювати добро i зло, вміти рішучо обирати правильне рішення. "Даремно навчатися і не мислити, мислити і не навчатись небезпечно” (1). Якщо зрозуміло, що є правильне і неправильне, якщо напрямок чіткий, а шлях правильний, тільки тоді наполеглива праця людей може приносити плоди. ...Необхідно сформувати правильний світогляд, погляди на життя, цінності, а оволодівши цим ключем, потім ще треба подивитися на суспільні явища, життєвий шлях, все правильне і неправильне, справжне і помилкове, головне та другорядне, все правдиве та хибне, добре і зле, красиве і потворне, а чітко все зрозумівши, цілком природньо можна винести правильне судження, зробити правильний вибір. Як то кажуть "Хоч і важко тисячі раз промивати пісок, але промивши до кінця, добудеш золото” (2)» [习近平谈治国理政 / 习近平著一北京：外文 出版社, 2014].

І знову посилання на тест “Луньюй” і висловлювання поета доби Тан:

(1) 学而不思则 罔, 思而不学则殆 (даремно навчатися і не мислити, мислити і не навчатись небезпечно) - “Луньюй”, глава “Вейчжен”.

(2) 千淘万漉虽辛苦, 吹尽狂沙始到金 (хоч і важко тисячі раз промивати пісок, але промивши до кінця добудеш золото) - Лю Юйсі, «Дев'ять віршів на мотив “лантаоша” (8-й)». Лю Юйсі (772-842), родом із міста Лоян (нині місто Лоян провінції Хенань). Літератор та філософ періоду династії Тан.

Звертаючись до молоді, Сі Цзіньпін говорить:

«По-четверте, ви повинні бути чесними, серйозно робити свою справу, практично ставати справжніми людьми. Моральність вимагає дії і не приймає порожніх розмов. Тільки докладаючи зусиль у реальних місцях, від поєднання знань та практики концепція основних цінностей може внутрішньо перетворитися на духовні прагнення людей, а назовні стати їх свідомими діями. У “Книзі ритуалів” (1) говориться: “Вивчай глибоко, будь допитливим, ретельно обмірковуй, будь розважливим, дій щиро”. (2) Хтось сказав: “Мудрець - це посередня людина, яка готова докладати зусиль для своєї справи, а посередня людина - це мудрець, який не бажає старанно працювати”. Молодь має великі шанси, ключовим тут є постійне просування вперед, зміцнення основи, тривалі зусилля. Неуважність та нестриманість, непостійність, перескакування 3 одного предмету на інший, з однієї справи на іншу, чи то в навчанні, чи у справі, є цілком недопустимим. "У Піднебесній важкі справи треба починати з легких, великі справи треба починати з малих”. (3) За успіхом завжди стоять 
важкі зусилля. Молодь повинна розглядати важкі умови праці як можливість загартувати себе, малі справи робити як важливі завдання, крок за кроком просуватись уперед. Крапля пробиває каміння. Якщо будете незламними, невтомними, то попереду вас обов'язково чекатиме успіх» [习近平谈治国理政 / 习近平著一北京: 外文出版社, 2014].

У цьому фрагменті виступу також посилання на конфуціанську класику i текст "Лаоцзи":

(1) “Ліцзі” (“Книга ритуалів”) - один із класичних канонів китайського конфуціанства, в якому розглядаються ситуація в суспільстві, система стародавніх законів і правил. Ідеї, що викладені у творі, стосуються сфер суспільства, політики, моралі, філософії, релігії тощо.

博学之, 审问之, 慎思之, 明辨之, 笃行之 (вивчай глибоко, будь допитливим, ретельно обмірковуй, будь розважливим, дій щиро) - “Ліцзі”, глава "Чжунюн”. "Чжунюн” - один із класичних канонів китайського конфуціанства. Початково був частиною канону “Ліцзі”, в епоху династії Сун цей текст було виокремлено, разом із “Дасюе”, “Луньюй”, “Менцзи” має назву “Чотири книги".

天下难事，必作于易; 天下大事，必作于细 (у Піднебесній важкі справи треба починати з легких, великі справи треба починати з малих) - “Лаоцзи”, глава 63. “Лаоцзи” - важливий філософський твір стародавнього Китаю, в якому висувається ідея, що “дао керує природою”, пропонується “управління шляхом не діяння".

У виступі на засіданні на честь святкування 65-річчя утворення Народної політичної консультативної ради Китаю 21 вересня 2014 року Сі Цзіньпін говорив:

"Успіх правління у відповідності сподіванням народу, поразка правління в діях проти сподівань народу”. Майбутня доля політичної партії, політичної сили в кінцевому підсумку залежить від симпатій і антипатій народу. Весь процес розвитку Комуністичної партії Китаю і Китайської Народної Республіки говорить нам про те, що успіхи, яких можуть досягти Комуністична партія Китаю і Китайська Народна Республіка, залежать від постійного збереження кровних зв'язків з народом, представлення корінних інтересів найширших мас народу» [习近平谈治国理政 / 习近平著 — 北京: 外文出版社, 2014].

Вислів “Успіх правління у відповідності сподіванням народу, поразка правління в діях проти сподівань народу” (政之所兴在顺民心, 政之所废在逆民心) вперше згадується в трактаті “Гуань-цзи”. “Гуань-цзи” - загальна назва низки давньокитайських філософських праць різних авторів, що жили в IV-III століттях до н. е. Цей твір увібрав у себе ідеї представників різних шкіл і напрямків, тому посідає особливе місце в історії суспільної думки Китаю. Цього принципу дотримувались не лише в конфуціанстві, але й в легізмі, вченні Моцзи та в інших філософських школах стародавнього Китаю.

Продовжуючи виступ, Сі Цзіньпін наголошує:

"Небо бачить очима народу, Небо чує слухом народу". Ми повинні здійснення, захист і розвиток корінних інтересів всього народу вважати відправною і кінцевою точкою всієї роботи, наша важлива робота і важливі рішення повинні бути зрозумілі і близькі простому народу” [习近平谈治国理政 / 习近 平著一北京: 外文出版社, 2014].

Вислів “Небо бачить очима народу, Небо чує слухом народу” (“天视自我民 视, 天听自我民听”) походить із тексту Тайши 泰誓 (Велика присяга, друга 
частина книги “Шаншу” “尚书”). Чжоуський правитель Уван 1048 року до н.е. пішов у похід проти тиранічного правителя династії Шан Ді Сіня. Перед походом Уван зібрав усіх князів і привів до присяги війська. Звідси назва тексту.

Далі цитата $з$ епохи Чуньцю:

«“Той, хто діє, завжди успішний, той, хто йде, завжди досягає мети”. Славна 65-річна історія НПКРК вже вписана в аннали історії. Для прекрасного майбутнього китайської нації необхідні одностайність і творення всіх синів і дочок Китаю. Давайте ще тісніше об'єднаємося, високо триматимемо великий прапор соціалізму з китайською специфікою, згуртовано і сміливо підемо вперед, здійснюючи відкриття та інновації, безперервно вписуючи нові глави до справ НПКРК!» [习近平谈治国理政 / 习近平著 一 北京：外文出版社，2014].

“Той, хто діє, завжди успішний, той, хто йде, завжди досягає мети” (“为者 常成, 行者常至。”) - цей вислів означає, що люди, які наполегливо працюють, часто можуть досягти успіху, а ті, хто невтомні, часто можуть досягти поставлених цілей, походить із тексту “晏子春秋·内篇杂下”.

“Яньцзи чуньцю” (“晏子春秋”) - твір історичної класики, в якому записані слова та вчинки політика царства Ці Янь Їна (晏婴) періоду Чуньцю (770 р. до н. е. -476 р. до н. е.). Книга укладена з історичних матеріалів та народних переказів. Янь Їн радив монарху бути старанним в управлінні країною, казав, що не слід прагнути до насолод, а треба дбати про народ, на службі використовувати мудрих і здібних, прислухуватись до порад, ставати прикладом для наступних поколінь. У минулому філологи вважали текст “Яньцзи чуньцю” підробкою, тривалий час не звертаючи на нього уваги. 1972 року розкопки ханьської гробниці в районі Їньцюешань виявили документи, що засвідчили справжність тексту “Яньцзи чуньцю”.

У наступній частині промови знову бачимо використання історичного прикладу:

«По-перше, слід дотримуватися переваг і особливостей системи соціалізму 3 китайською специфікою. "Взуття не повинно бути однаковим, головне, щоб підходило ногам; управління не повинно бути однаковим, головне, щоб приносило користь людям". Життєва сила системи соціалізму з китайською специфікою полягає в тому, що ця система виросла на грунті китайського суспільства, НПКРК відповідає національним умовам Китаю, має інституціональний порядок, що відрізняється яскравою китайською специфікою» [习近 平谈治国理政 / 习近平著一北京：外文出版社, 2014].

Висловлювання "Взуття не повинно бути однаковим, головне, щоб підходило ногам; управління не повинно бути однаковим, головне, щоб приносило користь людям” (“履不必同，期于适足；治不必同，期于利民。”) походить із книги Вей Юаня "Мо гу” (“默解”) у якій містяться філософські ідеї автора. Книга складається 3 двох частин: “Навчання" та “Управління”. Вей Юань 魏 源 $(23$ квітня 1794 - 26 березня 1857) - мислитель просвітництва, політик та літератор періоду династії Цін. Представник першої групи інтелектуалів сучасного Китаю, які придивлялися до світу за межами Китаю. Вей Юань виступав за вивчення передової західної науки і техніки. Це важливий символ переходу китайської думки від традиції до сучасності.

У промові "Підняти на новий рівень будівництво екологічної цивілізації в нашій країні" на Всекитайському з'їзді із захисту навколишнього середовища 18 травня 2018 року Сі Цзіньпін наводить приклади екологічної культури китайської нації $з$ давніх часів: 
«Будівництво екологічної цивілізації є основним державним планом, що впливає на сталий розвиток китайської нації. Китайська нація завжди поважала природу, любила природу. Китайська цивілізація, яка існує понад 5000 років, сформувала багату екологічну культуру. У “Книзі змін” говориться: “Вивчаючи рух світил, розуміють зміни часу, приділяючи увагу моральності, змінюють Піднебесну”, "розуміння законів неба і землі допомагає діяти відповідно до законів неба і землі”. У “Лаоцзи” говориться: “Людина підпорядковується землі, земля підпорядковується небу, небо підпорядковується Дао, Дао підпорядковується природі”. У “Менцзи” говориться: “Якщо не порушувати термінів польових робіт, то зерна буде в достатку; якщо в садки і ставки не запускати густі сітки, то риби і черепах буде стільки, що не з'їсти; якщо вчасно прийти в ліс із сокирою, то деревини буде з надлишком”. У “Сюньцзи” говориться: “Коли зацвітають дерева і трави, то не входять в ліс із сокирою, щоб не погубити їх зародження і зростання". У “Цімін яошу” $є$ такий опис: "Якщо вчасно визначити силу грунту, то витратиш менше сил і отримаєш більше”. Ці концепції наголошують на необхідності єдності людини, неба і землі, зв'язку природного середовища з людською цивілізацією, необхідності діяти відповідно до законів природи, брати вчасно, використовувати в міру, висловивши важливість розуміння нашими предками налагодження відносин між людиною і природою.

У той же час у стародавньому Китаї дуже рано поняття природного середовища було введено в систему державного управління, були спеціально створені установи, що відали лісами і водами, розроблена політика і закони, це була система піклувальників гір і озер. У “Чжоу лі” записано, що були розроблені “укази про гірських інспекторів, які опікувались гірськими лісами, для суворого дотримання законів”, “укази про перевірки лісничими лісів на схилах гір, про їх захист”. У період династій Цінь і Хань система піклувальників гір і озер складалася з чиновників лісів, чиновників озер, чиновників водойм, чиновників пасовищ, чиновників полів. Система піклувальників гір і озер проіснувала до династії Цін. У нашій країні в багатьох династіях були закони, які захищали природу і жорстоко карали порушників законів, наприклад, чжоуський Веньван видав "Указ про військові походи", що визначав: “Не можна руйнувати житло, не можна засипати колодязі, не можна рубати дерева, не можна забирати худобу. Той, хто порушив указ, карається смертю без помилування”》[推动我国生态文明建设迈上新台阶一一习近平在全国生态环境保护 大会上的讲话, 2018年5月18日].

Наведені тексти промов Сі Цзіньпіна свідчать про те, що на найвищому рівні в Китаї підкреслюється важливість наслідування традиційних моральних цінностей, традицій гуманного правління у дусі конфуціанства та прикладів дбайливого ставлення до навколишнього середовища.

Розглядаючи ці питання, слід зазначити, що у другій половині 2013 року пекінський фонд “修远” “Сююань” створив дослідницьку групу з традиційної культури, намагаючись відповісти на такі питання: що є стрижнем позачасових цінностей традиційної китайської культури; методологія традиційної культури в сучасну епоху; на яких аспектах традиційної культури слід зосередити увагу перед лицем викликів сучасності. Журнал "Веньхуа цзунхен” “文化纵 横” (“Питання культури”) 2014 року опублікував перші результати дослідження, що відображені в доповіді “Як нам сьогодні ставитися до традиційної культури” [我们今天应该如何面对传统文化。“文化纵横” 2014年第一期]. 
У доповіді зазначається, що на початку XX століття процес радикального анти-традиціоналізму породив спосіб мислення, який можна назвати “революційною діалектикою": виходячи 3 необхідності термінового порятунку країни, рух за нову культуру повністю заперечував культуру традиційну, остаточно став на шлях “навчання у Заходу”. Революційна діалектика означала, що, коли панівна група не бере на себе відповідальності, не представляє інтереси переважної більшості людей, то втрачає легітимність, і революція стає необхідною.

Китайські дослідники вважають, що з утворенням Нового Китаю, революційна діалектика певною мірою вже завершила свою історичну місію. Особливо сьогодні, коли Китай прагне до створення “гармонійного суспільства”, підкреслюється необхідність зосередитися на новому загальному розумінні реформ, приділяти більше уваги “узгодженості і рівновазі". Автори доповіді нагадують, що ще Мао Цзедун у статті "Про десять основних відносин” вже використав цей підхід. У статті він не тільки пояснив поділ, але підкреслив єдність протилежностей, не підкреслював придушення одного одним. У народі між центральною і місцевою владою, між містом і селом, між регіонами $є$ суперечності, але слід уникати розвитку суперечностей у протистояння, необхідно “у співпраці отримувати взаємний виграш”.

Стрижнем такого діалектичного методу, де приділяється увага рівновазі, $\epsilon$ акцент на єдності протилежностей - знати про наявність протилежностей, але робити наголос на єдності. У доповіді підкреслюється, що такий спосіб мислення має внутрішню узгодженість 3 ідеєю серединного шляху в конфуціанстві. Серединний шлях є головним принципом і методом розв'язання суперечностей в конфуціанській традиції - використовуючи сучасні поняття його також можна назвати “консервативною діалектикою”. Конфуціанська традиція підкреслює необхідність збереження відносин між правителем і підданим, батьком і сином, чоловіком і дружиною, старшим і молодшим братом, центральною та місцевою владою, між Китаєм та іншими країнами. Основною ідеєю є принцип золотої середини, суть якого в прагненні до рівноправності відмінностей.

Обговорюючи конфуціанську традицію, автори доповіді вважають, що слід не просто згадати про конфуціанську етику, але й сприйняти ефективну частину західної етики, яка заснована на правах особистості, створити етику балансу прав і обов'язків.

Китай на цей час стикається з двома основними викликами. По-перше, тенденція величезних змін у світі: одночасно відбуваються глобалізація, комерціалізація, індустріалізація, урбанізація, інформатизація. У таких умовах змін, підтримання соціальної стабільності, узгодження різних інтересів стають все складнішими. Другим викликом є посилення міжнародної конкуренції: між економіками, що народжуються, і розвиненими економіками існують потужні технічні та інституційні бар'єри. Світова система торгівлі та світова економічна система, що контролюються еконо мічними структурами розвинених країн, безперервно використовують економічні плоди інших країн. Щоб вирватися 3 цієї незбалансованої економічної структури, необхідний потенціал могутніх держав, заклик єдиного органу ухвалення рішень.

У західній історії існує багатий досвід місцевого самоврядування, але відсутній досвід управління перетвореннями великої країни. Якщо говорити про Китай, то йому необхідно одночасно відповідати на два виклики: управ- 
ління перетвореннями та управління у великій країні. Управління перетвореннями у великій країні стоїть перед проблемою: і зберігати стабільність, i розвиватися. В управлінні перетвореннями можна запозичувати досвід 3 історііิ трансформації різних країн, але досвід управління великою країною можна знайти в історії Китаю.

Історія єдиної держави в Китаї налічує більш ніж два тисячоліття. Як зазначав відомий китайський історик Цянь Му, в історії Китаю розвивалася цілісна система державного управління “вченими-політиками”, яка на відміну від Заходу, забезпечувала тривалу стабільність політичного порядку, зберігала наступність цивілізації. Найбільшою перевагою системи “вчених-політиків" $\epsilon$ забезпечення теоретичної, політичної та організаційної єдності панівної групи. Панівна група на основі конфуціанського принципу “народ - основа влади" робила наголос на “самовдосконаленні, наведенні порядку в родині, управлінні державою, умиротворенні Піднебесної”. Тут дуже важливим є аспект політичного “почуття відповідальності", що значно відрізняється від характерної особливості політичного “представництва” західних класових політичних партій. 3 точки зору сучасної політики, нинішня політична система Китаю є однопартійною, але 3 точки зору традиції, однопартійна влада Китаю продовжує історичну інерцію “вчених-політиків".

Традиція “вчених-політиків” не тільки містить політичні ідеї, а й розробила методи управління, наприклад, систему управління провінціями і повітами, систему державних іспитів тощо. Про ці ідеї і досвід управління єдиною великою країною сьогодні неможливо судити і відкидати їх на підставі західних політичних концепцій “східного деспотизму”, “феодалізму” та ін. I як саме оцінити традиційний китайський досвід управління, як виявити його внутрішню цінність, є історичним завданням, за яке повинні нести відповідальність нинішні китайські інтелектуали.

Як світська цивілізація, китайська цивілізація не має потужної релігійної традиції, доцентрова сила цієї цивілізації грунтується на усвідомленні історії. Історія для китайського народу рівнозначна релігійним цінностям і переконанням, $є$ унікальним способом розуміння світу. До теперішнього часу цей основний спосіб мислення не змінився.

На думку укладачів доповіді, між китайською традиційною ідеологією і соціалізмом вже існує тісний зв'язок. У стародавньому Китаї, в економічній сфері завжди підкреслювалося, що “у кого є постійний дохід, той має сталість”. Конфуціанська традиція завжди будувала соціальну стабільність на основі рівномірного, сталого розподілу земельних ресурсів, для спільного життя більшості людей, а не капіталістичними методами залякування. Це узгоджується із соціалістичною ідеологією сучасного Китаю. У сфері суспільного життя конфуціанська традиційна ідеологія часто підкреслює узгодженість, підкреслює взаємопо'язаність, підкреслює, що суспільство являє собою органічне ціле. Кожна людина відповідає за інших людей, що в широкому сенсі слова відповідає соціалізму. У цьому сенсі соціалізм і конфуціанство взаємно пояснюють один одного, доходять висновку укладачі доповіді “Як нам сьогодні ставитися до традиційної культури". Такий погляд підтверждується історичними алюзіями у текстах промов Сі Цзіньпіна.

Таким чином, розвиток сучасного Китаю спирається на поєднання ідей XIX-XX сторіч та історичного досвіду китайської цивілізації в управлінні державою 3 часів формування конфуціанства. У цьому і полягає китайська специфіка. 


\section{ЛІТЕРАТУРА}

习近平谈治国理政 / 习近平著 一 北京: 外文出版社, 2014. (Сі Цзіньпін про державне управління / Сі Цзіньпін - Пекін: Видавництво літератури іноземними мовами, 2014).

推动我国生态文明建设迈上新台阶一一习近平在全国生态环境保护大会上 的讲话, 2018年5月18日 (Підняти на новий рівень будівництво екологічної цивілізації в нашій країні - промова Сі Цзіньпіна на Всекитайському з’їзді із захисту навколишнього середовища. 18 травня 2018 року) http://news.cyol.com/ content/2019-01/31/content 17908057.htm

我们今天应该如何面对传统文化。“文化纵横” 2014年第一期。(Як нам сьогодні ставитись до традиційної культури. "Веньхуа цзунхен” №1, 2014 р.).

\section{REFERENCES}

Xí Jìnpíng tán zhìguó lǐ zhèng/ Xí Jìnpíng zhe - Běijīng: Wàiwén chūbănshè, 2014.

Tuīdòng wǒguó shēngtài wénmíng jiànshè màishàng xīn táijiē-Xí Jìnpíng zài quánguó shēngtài huánjìng băohù dàhuì shàng de jiănghuà, 2018.05.18. http:// news.cyol.com/content/2019-01/31/content 17908057.htm

Wǒmen jīntiān yìng gāi rúhé miànduì chuántǒng wénhuà. "Wénhuà zònghéng", 2014, № 1 .

\section{ІСТОРИЧНІ АЛЮЗІЇ У ТЕКСТАХ ПРОМОВ СІ ЦЗІНЬПІНА}

\section{В. Б. Урусов}

У статті розглянуті приклади історичних алюзій у текстах промов Сі Цзіньпіна. Дано пояснення джерел висловлювань із китайської класики. Вказано на значення історичної спадщини конфуціанства та традицій державного управління давнини для розвитку китайського суспільства з точки зору сучасних китайських дослідників.

Ключові слова: історичні алюзії, основні цінності соціалізму, соціалізм із китайською специфікою, традиційна культура, конфуціанство

\section{ИСТОРИЧЕСКИЕ АЛЛЮЗИИ В ТЕКСТАХ РЕЧЕЙ СИ ЦЗИНЬПИНА}

В. Б. Урусов

В статье рассмотрены примеры исторических аллюзий в текстах речей Си Цзиньпина. Дано объяснение источников высказываний из китайской классики. Указано на значение исторического наследия конфуцианства и традиций государственного управления древности для развития китайского общества с точки зрения современных китайских исследователей.

Ключевые слова: исторические аллюзии, основные ценности социализма, социализм с китайской спецификой, традиционная культура, конфуцианство 